\title{
Protein expression of c-erbB-2 and p53 in normal ducts, ductal carcinoma in situ and invasive carcinoma of the same breast
}

\author{
Centro de Atenção Integral à Saúde da Mulher, Universidade Estadual de \\ Campinas (CAISM/Unicamp), Campinas, São Paulo, Brazil
}

\section{INTREDUCTION}

Breast cancer is thought to derive from progressively aberrant, non-invasive breast lesions such as atypical hyperplasia and ductal carcinoma in situ, but it is not known exactly how invasive breast cancer develops from these lesions. Chromosomal imbalances occur, with gain or loss at multiple loci, as hyperplastic lesions progress from ductal carcinoma in situ to invasive breast cancer. ${ }^{1,2}$ Nevertheless, the presence of shared chromosomal changes in both ductal carcinoma in situ and synchronous, adjacent invasive cancers demonstrates their clonal, evolutionary relationship. ${ }^{3}$

HER-2/neu and TP53 gene expression in normal breast tissue is different from what is found in invasive breast carcinoma, and this variation can be assessed by immunohistochemistry. ${ }^{4,5}$ Many studies have already analyzed c-erbB- 2 and $\mathrm{p} 53$ protein expression in ductal carcinoma in situ and invasive ductal carcinoma, but most of these studies were carried out in tissue from different women, thereby restricting the usefulness of these data for studying tumor progression..$^{4,5}$

Progression from ductal carcinoma in situ to invasive carcinoma occurs at specific points within the preexisting in situ lesion, and therefore ductal carcinoma in situ and invasive ductal carcinoma are frequently found in the same breast. ${ }^{6}$ We made the assumption that such cases would be a good model in which to study the relationship between non-neoplastic ducts, ductal carcinoma in situ and invasive ductal carcinoma.

口BJECTIVE

The aim of this study was to verify the changes in protein expression between nonneoplastic ducts, ductal carcinoma in situ and invasive ductal carcinoma found in the same breast. materials AND METHODS

Ninety-eight women diagnosed with invasive ductal carcinoma and ductal carcinoma in situ in the same breast were selected consecutively for this study. The patients were seen in our service (Centro de Atenção Integral à Saúde da Mulher, CAISM) or in a private medical service in Campinas, São Paulo, Brazil, between 1994 and 1999. The paraffin-embedded blocks were sectioned and the slides were stained with hematoxylin-eosin to identify the tissue areas in which non-neoplastic ducts, ductal carcinoma in situ and invasive ductal carcinoma were found. Forty-two of these women were excluded from the study because the remaining breast tissue in the paraffin blocks was insufficient for immunohistochemical analysis. The remaining fifty-six women were enrolled in the study: thirty-eight of them were diagnosed as having invasive ductal carcinoma in clinical stage I and eighteen in stage II. Less prevalent histological types were not included, in order to obtain a homogeneous sample.

The same pathologist performed the pathoanatomical analyses and established the final histological diagnosis. Ducts were defined as non-neoplastic when they were normal ducts (one layer of cells) or presented typical ductal hyperplasia (up to four layers of cells without atypia). The nuclear grade of tissue components was also evaluated and classified according to the 1997 Consensus Conference on the Classification of Ductal Carcinoma In Situ. ${ }^{7}$

The expression of c-erbB-2 and p53 proteins was assessed using immunohistochemistry. Specific monoclonal primary antibodies for c-erbB-2 ( $\mathrm{RxH}$, Dako, code A0485-1, at 1:300 dilution) and for p53 (MxH, clone D07, Dako, code M7001-1, at 1:100 dilution) were used, and steam heating was used to unmask the antigens. The slides were incubated using Envision
- Marcus Vinicius Martins de Menezes

- Anna Letícia Oliveira Cestari

- Orlando Almeida

- Marcelo Alvarenga

- Glauce Aparecida Pinto

- Maria Salete Costa Gurgel

- Gustavo Antônio de Souza

- Luiz Carlos Zeferino

\section{ABSTRACT}

CONTEXT AND OBJECTIVE: Breast cance is thought to derive from progressively aberrant non-invasive breast lesions, but it is not known exactly how invasive breast cancer develops from these lesions. The aim of this study was to verify the changes in c-erbB-2 and p53 protein expression between non-neoplastic ducts, ducta carcinoma in situ and invasive ductal carcinoma found in the same breast

DESIGN AND SETTING: This was a crosssectional study at Centro de Atenção Integral à Saúde da Mulher, Campinas, Brazil.

METHODS: Fiffy-six women with invasive ductal carcinoma and ductal carcinoma in situ in the same breast were included. The expression of c-erbB-2 and p53 proteins was assessed in non-neoplastic and neoplastic cells using immunohistochemical techniques.

RESULTS: The c-erbB-2 protein was absent in non-neoplastic ducts but was present in $46 \%$ and $36 \%$ of in situ and invasive carcinoma components, respectively. Only $2 \%$ of non-neoplastic ducts, and $18 \%$ and $16 \%$ of ductal carcinoma in situ and invasive carcinoma components, respectively, were positive for $\mathrm{p} 53$ protein. No significant difference in c-erbB-2 and p53 protein expression was observed between in situ and invasive components. The nuclear grade agreement between in situ and invasive carcinoma was very good.

CONCLUSIONS: The invasiveness of ducta carcinoma in situ seems to be independent of the Her-2/neu and TP53 genes. The general features of an occurrence of breast carcinoma are formulated at the outset of carcinogenesis, and the Her-2/neu and TP53 genes are involved.

KEY WORDS: Breast neoplasms. Ductal carcinoma in situ. Carcinoma. Receptor erbB-2. Protein p53. 
labeled polymer components (Dako, code K1491). Development was carried out using DAB (3-3'-diaminobenzidine, Sigma, code D5637). All immunohistochemical assays were performed using external positive controls: invasive ductal carcinoma for c-erbB-2 and borderline ovarian tumor for $\mathrm{p} 53$.

Immunohistochemical analysis was carried out using 40x magnification, by a single pathologist who was blinded to the results from the pathoanatomical analyses. The c-erbB-2 protein expression was considered positive when more than $10 \%$ of the cells were stained, and $\mathrm{p} 53$ protein expression was considered positive when more than $1 \%$ of the nuclei were stained, regardless of the intensity of the staining.

Odds ratios were used to evaluate the strength of the association between pairs of variables, and the $95 \%$ confidence intervals (CI) were calculated. The kappa coefficient was used to verify the agreement between the nuclear grade of ductal carcinoma in situ and the nuclear grade of invasive ductal carcinoma in the same breast, and was classified as: poor $(<0.20)$; fair $(0.21-0.40)$; moderate (0.41-0.60); good (0.61-0.80) or very good (0.81-1.00). ${ }^{8}$ For statistical purposes, nuclear grades 1 and 2 were analyzed together.

RESULTS

The c-erbB-2 protein was absent from nonneoplastic ducts but was present in $46 \%$ of the cases of ductal carcinoma in situ, resulting in an odds ratio of 98.18 (95\% CI: 5.781667.60). There was no statistical difference in c-erbB-2 expression between in situ and invasive components. Only $2 \%$ of the non-

Table 1. Association of protein expression of c-erbB-2 and p53 in non-neoplastic ducts, ductal carcinoma in situ and invasive ductal carcinoma of the same breast

\begin{tabular}{|c|c|c|c|}
\hline \multirow{2}{*}{ Protein expression } & $\begin{array}{c}\text { Non-neoplastic } \\
\text { ducts }\end{array}$ & $\begin{array}{c}\text { Ductal carcinoma } \\
\text { in situ }\end{array}$ & $\begin{array}{c}\text { Invasive ductal } \\
\text { carcinoma }\end{array}$ \\
\hline & n (\%) & n (\%) & $n(\%)$ \\
\hline c-erbB-2 positive & $0(0)$ & $26(46)$ & $20(36)$ \\
\hline c-erbB-2 negative & $56(100)$ & $30(54)$ & $36(64)$ \\
\hline OR $(95 \% \mathrm{CI})^{*}$ & \multicolumn{2}{|c|}{$98.2(5.8-1667.6)$} & $0.6(0.3-1.4)$ \\
\hline p53 positive & $1(2)$ & $10(18)$ & $9(16)$ \\
\hline p53 negative & $55(98)$ & $46(82)$ & $47(84)$ \\
\hline OR $(95 \% \mathrm{CI})^{*}$ & \multicolumn{2}{|c|}{$12.0(1.5-96.9)$} & $0.9(0.3-2.4)$ \\
\hline Total cases & $56(100)$ & $56(100)$ & $56(100)$ \\
\hline
\end{tabular}

$O R=$ odds ratio; $95 \% \mathrm{Cl}=95 \%$ confidence interval. ${ }^{*}=$ Both $O R$ included data referring to ductal carcinoma in situ.

Table 2. Association of c-erbB-2 and p53 protein expression according to nuclear grade of ductal carcinoma in situ and invasive ductal carcinoma of the same breast

\begin{tabular}{|c|c|c|c|c|c|c|}
\hline \multirow[b]{2}{*}{ Protein expression } & \multicolumn{3}{|c|}{ Ductal carcinoma in situ } & \multicolumn{3}{|c|}{ Invasive ductal carcinoma } \\
\hline & $\begin{array}{c}\text { NG } 1 \text { or } 2 \\
\text { n (\%) }\end{array}$ & $\begin{array}{l}\text { NG } 3 \\
\text { n (\%) } \\
\end{array}$ & OR $(95 \% \mathrm{Cl})$ & $\begin{array}{c}\text { NG } 1 \text { or } 2 \\
n(\%)\end{array}$ & $\begin{array}{l}\text { NG } 3 \\
\text { n (\%) } \\
\end{array}$ & OR $(95 \% \mathrm{Cl})$ \\
\hline c-erbB-2 positive & $8(27)$ & $18(69)$ & $6.2(2.0-19.8)$ & $6(18)$ & $14(61)$ & $7.0(2.1-23.7)$ \\
\hline p53 positive & 2 (7) & $8(31)$ & $6.2(1.2-32.7)$ & $1(3)$ & $8(35)$ & $17.1(2.0-149.1)$ \\
\hline Total cases* & $30(100)$ & $26(100)$ & & $33(100)$ & $23(100)$ & \\
\hline
\end{tabular}

$O R=$ odds ratio; $95 \% \mathrm{Cl}=95 \%$ confidence interval; $N G=$ nuclear grade. *Positive plus negative protein expression cases.

Table 3. Distribution of cases according to the nuclear grade of ductal carcinoma in situ and invasive ductal carcinoma of the same breast: analysis of nuclear grade agreement

\begin{tabular}{lcccc}
\hline $\begin{array}{l}\text { Invasive ductal } \\
\text { carcinoma }\end{array}$ & NG 1 & NG 2 & NG 3 & Total \\
\cline { 2 - 5 } NG 1 & 6 & 1 & 0 & $\mathbf{n}(\%)$ \\
NG 2 & 0 & 23 & 3 & $7(12.5)$ \\
NG 3 & 0 & 0 & 23 & $26(46.4)$ \\
Total & $6(10.7)$ & $24(42.9)$ & $26(46.4)$ & $23(41.1)$ \\
\hline Kappa coefficient $(\mathbf{9 5 \% ~ C l ) : 0 . 8 8 ~ ( 0 . 7 7 - 0 . 9 9 ) ~}$ & & \\
\hline NG = nuclear grade; $95 \% \mathrm{Cl}=95 \%$ confidence interval.
\end{tabular}

neoplastic ducts and $18 \%$ of the ductal carcinoma in situ components showed $\mathrm{p} 53$ protein expression, resulting in an odds ratio of 11.96 (95\% CI: 1.47-96.92), while the difference in p53 positivity between ductal carcinoma in situ and invasive ductal carcinoma gave a nonsignificant result (Table 1). Every case with positive c-erbB-2 expression in the invasive carcinoma component showed also positive expression in the in situ component. Eight out of the nine cases with positive $\mathrm{p} 53$ expression in the invasive component also showed positive expression in the in situ component (data not shown).

Positive c-erbB-2 protein expression was associated with nuclear grade 3 in both the in situ and the invasive components of ductal carcinoma. The $\mathrm{p} 53$ protein expression showed a similar association (Table 2). There were no cases of invasive ductal carcinoma with a higher nuclear grade than what was found in the ductal carcinoma in situ component, and in 52/56 cases both components were found to have the same nuclear grade. The kappa coefficient was 0.88 (0.77-0.99), thus indicating very good agreement (Table 3 ).

\section{DISCUSSIRN}

The expression of c-erbB-2 and p53 proteins showed a large variation between the non-neoplastic ducts and ductal carcinoma in situ components, but most of the cases showed very similar protein expression and good nuclear grade agreement between ductal carcinoma in situ and invasive ductal carcinoma components.

C-erbB-2 protein expression has not been found in either normal breast tissue or ductal hyperplasia, and there is a broad consensus regarding these results. ${ }^{9-13} \mathrm{~A}$ few studies have reported expression of this protein in rare cases of atypical ductal hyperplasia, ${ }^{14-16}$ and there could be two possible explanations for these findings. First, these rare cases could be genetically different and, second, the interobserver reproducibility of borderline lesions with these diagnostic criteria is poor. Atypical ductal hyperplasia with c-erbB-2 positive expression may have been classified as well-differentiated ductal carcinoma in situ by other observers. ${ }^{17} \mathrm{Few}$ cases of well-differentiated ductal carcinoma in situ show c-erbB-2 protein expression., ${ }^{3,5}$

A review ${ }^{18}$ has shown that overall c-erbB-2 positivity for all types of ductal carcinoma in situ ranges between $21 \%$ and $64 \%$, and for comedo ductal carcinoma in situ between $62 \%$ and $81 \%$. The positivity is lower in cases of invasive ductal carcinoma, ranging 
between $16 \%$ and $40 \%,{ }^{18}$ and these data are in agreement with the results from the present study. There is also a clear association between c-erbB-2 positivity and worse nuclear and histological grades, tumor aneuploidy and high rate of proliferation, and this is more frequent in ductal carcinoma in situ than in invasive ductal carcinoma. ${ }^{5,18,19}$ This profile for c-erbB-2 protein expression is quite similar to the $\mathrm{p} 53$ protein expression profile. ${ }^{20,21}$

The morphological features and immunohistochemical profile of the ductal carcinoma in situ and invasive ductal carcinoma components of the same specimens have been found to be very similar. ${ }^{5,22}$ Cases of ductal carcinoma in situ have shown a more "malignant picture" than cases of invasive cancer. ${ }^{5,19}$ In the present study, fifty-two out of fifty-six cases showed ductal carcinoma in situ and invasive ductal carcinoma components with the same nuclear grade, while in the other four cases, more malignant features were found in the ductal carcinoma in situ component. This may suggest that undifferentiation and invasiveness of the ductal carcinoma in situ are not necessarily associated. Similar results were obtained by Warnberg et al. ${ }^{5}$ when comparing the nuclear grades of ductal carcinoma in situ and invasive ductal carcinoma in the same breast. There was concordance between the nuclear grades of ductal carcinoma in situ and invasive ductal carcinoma in 102 cases out of 259. In 151 cases, the nuclear grade was higher in ductal carcinoma in situ than in invasive ductal carcinoma, and in only six cases was the nuclear grade of invasive ductal carcinoma higher than that of ductal carcinoma in situ. These data suggest that the degree of aggressiveness of the tumor, i.e. its prognosis, is genetically "formulated" at the beginning of carcinogenesis and is maintained throughout the evolution of the disease.

A study of gene expression patterns in ductal carcinoma in situ and invasive ductal carcinoma, carried out using serial analysis of gene expression (SAGE), found that the most dramatic transcriptome change occurs at the time of transition from normal to ductal carcinoma in situ, when there is no clear universal "in situ" or "invasive" molecular signature of the tumor. That study suggested that some genes may be able to define biologically and clinically meaningful subgroups of ductal carcinoma in situ with a high risk of progression to invasive disease. ${ }^{23}$

Another study using microdissection and DNA microarrays revealed extensive similarities at the transcriptome level among the distinct stages of progression and suggested that gene expression alterations that conferred the potential for invasive growth are already present in the preinvasive stages. In contrast, different tumor grades are associated with distinct gene expression signatures. Furthermore, a subset of genes associated with high tumor grade is quantitatively correlated with the transition from preinvasive to invasive growth. ${ }^{24}$

Atypical ductal hyperplasia is an early aberrant breast lesion that may progress to low nuclear grade ductal carcinoma in situ, which would continue accumulating genetic alterations ${ }^{13}$ and could lead progressively to intermediate and high nuclear grade ductal carcinoma in situ.

Considering the findings of these studies, the ductal carcinoma in situ cells could acquire the ability to cross the basal membrane and trigger an invasive ductal carcinoma with very similar morphological and immunohistochemical features. Therefore, a low-grade ductal carcinoma in situ could trigger a low-grade invasive ductal carcinoma and the same could occur in cases of intermediate and high-grade tumors. The in situ ductal carcinomas that do not become invasive at an early stage would reach high nuclear grade and would proliferate along the mammary duct, thus accumulating areas of necrosis and calcification.
There are two possible explanations for the few cases in our study in which the ductal carcinoma in situ component showed a higher nuclear grade than did the invasive ductal carcinoma component. First, the cellular clone that becomes invasive may be more differentiated than the other clones present in the ductal carcinoma in situ component. Second, after invasion has occurred, the remaining ductal carcinoma in situ component would continue accumulating genetic alterations, thereby reaching higher nuclear grades than the cellular clone from which the invasive ductal carcinoma originated.

In short, the results from our study suggest that the Her-2/neu and TP53 genes are likely to be involved in the beginning of breast carcinogenesis (induction) and undifferentiation of ductal carcinoma in situ, but not in the progression from ductal carcinoma in situ to invasive carcinoma. We must emphasize that the variation in c-erbB-2 protein expression in the three components of the same specimens is due exclusively to local modifications of ductal cells, since there are no genetic differences other than those acquired over the course of the evolution of carcinogenesis. Studies carried out on ductal carcinoma in situ and invasive ductal carcinoma in different women are biased by individual genetic differences.

CONCLUSIONS

The invasiveness of ductal carcinoma in situ seems to be independent of the Her-2/neu and TP53 genes. Our results suggest that the general features of breast carcinoma occurrences are formulated at the outset of carcinogenesis, and that the Her-2/neu and TP53 genes are involved in this. The morphological features and immunohistochemical profile of the ductal carcinoma in situ and invasive ductal carcinoma components of the same specimens are very similar.
1. Farabegoli F, Champeme MH, Bieche I, et al. Genetic pathways in the evolution of breast ductal carcinoma in situ. J Pathol. 2002;196(3):280-6.

2. Burstein HJ, Polyak K, Wong JS, Lester SC, Kaelin CM. Ductal carcinoma in situ of the breast. N Engl J Med. 2004;350(14):1430-41

3. Aubele MM, Cummings MC, Mattis AE, et al. Accumulation of chromosomal imbalances from intraductal proliferative lesions to adjacent in situ and invasive ductal breast cancer. Diagn $\mathrm{Mol}$ Pathol. 2000;9(1):14-9.
4. Mommers EC, Leonhart AM, Falix F, et al. Similarity in expression of cell cycle proteins between in situ and invasive ductal breast lesions of same differentiation grade. J Pathol. 2001;194(3):327-33.

5. Warnberg F, Nordgren H, Bergkvist L, Holmberg L. Tumour markers in breast carcinoma correlate with grade rather than with invasiveness. Br J Cancer. 2001;85(6):869-74

6. Goldstein NS, Murphy T. Intraductal carcinoma associated with invasive carcinoma of the breast. A comparison of the two lesions with implications for intraductal carcinoma classification systems. Am J Clin Pathol. 1996;106(3):312-8.
7. Consensus Conference on the classification of ductal carcinoma in situ. The Consensus Conference Committee. Cancer. 1997;80(9):1798-802.

8. Altman DG. Practical statistics for medical research. London Chapman \& Hall; 1991.

9. De Potter CR, Van Daelle S, Van de Vijver MJ, et al. The expression of the neu oncogene product in breast lesions and in normal fetal and adult human tissues. Histopathology. 1989;15(4):351-62.

10. Umekita Y, Takasaki T, Yoshida H. Expression of p53 protein in benign epithelial hyperplasia, atypical ductal hyperplasia, 
non-invasive and invasive mammary carcinoma: an immunohistochemical study. Virchows Arch. 1994;424(5):491-4.

11. Allred DC, Clark GM, Molina R, et al. Overexpression of HER$2 /$ neu and its relationship with other prognostic factors change during the progression of in situ to invasive breast cancer. Hum Pathol. 1992;23(9):974-9.

12. Allred DC, Harvey JM, Berardo M, Clark GM. Prognostic and predictive factors in breast cancer by immunohistochemical analysis. Mod Pathol. 1998;11(2):155-68.

13. Aubele $\mathrm{M}$, Werner $\mathrm{M}, \mathrm{Höfler} \mathrm{H}$. Genetic alterations in presumptive precursor lesions of breast carcinomas. Anal Cell Pathol. 2002;24(2-3):69-76.

14. Allred DC, Mohsin SK, Fuqua SA. Histological and biological evolution of human premalignant breast disease. Endocr Relat Cancer. 2001;8(1):47-61.

15. Coene ED, Schelfhout V, Winkler RA, et al. Amplification units and translocation at chromosome $17 \mathrm{q}$ and c-erbB-2 overexpression in the pathogenesis of breast cancer. Virchows Arch. 1997;430(5):365-72.

16. Heffelfinger SC, Yassin R, Miller MA, Lower EE. Cyclin D1, retinoblastoma, $\mathrm{p} 53$, and $\mathrm{Her} 2 /$ neu protein expression in preinvasive breast pathologies: correlation with vascularity. Pathobiology. 2000;68(3):129-36.
17. Schnitt SJ, Connolly JL, Tavassoli FA, et al. Interobserver reproducibility in the diagnosis of ductal proliferative breast lesions using standardized criteria. Am J Surg Pathol 1992;16(12):1133-43

18. Révillion F, Bonneterre J, Peyrat JP. ERBB2 oncogene in human breast cancer and its clinical significance. Eur J Cancer 1998;34(6):791-808

19. Warnberg F, Casalini P, Nordgren H, Bergkvist L, Holmberg L, Menard S. Ductal carcinoma in situ of the breast: a new phenotype classification system and its relation to prognosis. Breast Cancer Res Treat. 2002;73(3):215-21.

20. Alexiev BA, Bassarova AV, Popovska SL, Popov AA, Christov CZ. Expression of c-erbB-2 oncogene and $\mathrm{p} 53$ tumor suppressor gene in benign and malignant breast tissue: correlation with proliferative activity and prognostic index. Gen Diagn Pathol. 1997;142(5-6):271-9.

21. Viacava P, Naccarato AG, Bevilacqua G. Different proliferative patterns characterize different preinvasive breast lesions. J Pathol. 1999;188(3):245-51.

22. Giardina C, Serio G, Lepore G, et al. Pure ductal carcinoma in situ and in situ component of ductal invasive carcinoma of the breast. A preliminary morphometric study. J Exp Clin Cancer Res. 2003;22(2):279-88.
23. Porter D, Lahti-Domenici J, Keshaviah A, et al. Molecular markers in ductal carcinoma in situ of the breast. Mol Cance Res. 2003;1(5):362-75.

24. Ma XJ, Salunga R, Tuggle JT, et al. Gene expression profiles of human breast cancer progression. Proc Natl Acad Sci U S A. 2003;100(10):5974-9.

\section{AUTHOR INFORMATION}

Marcus Vinicius Martins de Menezes, MD. Department of Obstetrics and Gynecology, Faculdade de Ciências Médicas da Universidade Estadual de Campinas (Unicamp), Campinas, São Paulo, Brazil.

Anna Letícia Oliveira Cestari, MD. Department of Obstetrics and Gynecology, Faculdade de Ciências Médicas da Universidade Estadual de Campinas (Unicamp), Campinas, São Paulo, Brazil.

Orlando Almeida, MD, PhD. Department of Obstetrics and Gynecology, Faculdade de Ciências Médicas da Universidade Estadual de Campinas (Unicamp), Campinas, São Paulo, Brazil.

Marcelo Alvarenga, MD, PhD. Department of Obstetrics and Gynecology, Faculdade de Ciências Médicas da Universidade Estadual de Campinas; and Centro de Atenção Integral à Saúde da Mulher (CAISM/Unicamp), Campinas, São Paulo, Brazil

Glauce Aparecida Pinto, PhD. Centro de Atenção Integral à Saúde da Mulher, Universidade Estadual de Campinas (CAISM/Unicamp), Campinas, São Paulo, Brazil.

Maria Salete Costa Gurgel, MD, PhD. Department of Obstetrics and Gynecology, Faculdade de Ciências Médicas da Universidade Estadual de Campinas (Unicamp), Campinas, São Paulo, Brazil.

Gustavo Antonio de Souza, MD, PhD. Department of Obstetrics and Gynecology, Faculdade de Ciências Médicas da Universidade Estadual de Campinas; and Centro de Atenção Integral à Saúde da Mulher, (CAISM/Unicamp), Campinas, São Paulo, Brazil.

Luiz Carlos Zeferino, MD, PhD. Department of Obstetrics and Gynecology, Faculdade de Ciências Médicas da Universidade Estadual de Campinas; and Centro de Atenção Integral à Saúde da Mulher (CAISM/Unicamp), Campinas, São Paulo, Brazil.

Address for correspondence:

Luiz Carlos Zeferino

Departamento de Tocoginecologia e Obstetrícia

- Centro de Atenção Integral à Saúde da Mulher (CAISM/Unicamp)

Rua Alexander Fleming, 101

Cidade Universitária Zeferino Vaz Campinas

São Paulo (SP) - Brasil - CEP 13083-970

Tel. (+55 19) 3788-9516

Fax (+55 19) 3788-9302

E-mail: zeferino@caism.unicamp.br

Copyright (๑) 2006, Associação Paulista de Medicina
Sources of funding: Fundação de Amparo à Pesquisa do Estado de São Paulo (Fapesp) - Grant no. 00/00032-0. Fundo de Apoio ao Ensino e Pesquisa da Unicamp (Faep) - Grant no. 1220/01.

Conflict of interest: Not declared

Date of first submission: November 8, 2004

Last received: May 10, 2006

Accepted: May 18, 2006

RESUMD

Expressão das proteínas c-erbB-2 e p53 nos ductos normais, carcinoma ductal in situ e carcinoma invasivo da mesma mama

CONTEXTO E OBJETIVO: $\bigcirc$ câncer de mama se origina de lesões não-invasivas, tais como as hiperplasias atípicas e o carcinoma ductal in situ, porém não se sabe exatamente como o câncer se torna invasivo. $O$ objetivo foi verificar alterações na expressão das proteínas c-erbB-2 e p53 entre ductos não-neoplásicos, carcinoma ductal in situ e carcinoma ductal invasivo presentes na mesma mama.

TIPO DE ESTUDO E LOCAL: Estudo transversal, realizado no Centro de Atenção Integral à Saúde da Mulher, Campinas, São Paulo, Brasil.

MÉTODOS: Cinqüenta e seis mulheres com o diagnóstico de carcinoma ductal invasivo e carcinoma ductal in situ na mesma mama foram selecionadas e incluídas neste estudo. A expressão das proteínas c-erbB-2 e p53 foi avaliada usando imunoistoquímica.

RESULTADOS: A proteína c-erbB-2 estava ausente nos ductos não-neoplásicos, mas estava presente em $46 \%$ e $36 \%$, respectivamente, dos componentes de carcinomas in situ e invasivos. Apenas $2 \%$ dos ductos nãoneoplásicos, $18 \%$ e $16 \%$ dos carcinomas in situ e carcinomas invasivos, respectivamente, foram positivos para a proteína p53. Não houve diferença significativa na expressão das proteínas c-erbB-2 e p53 entre os carcinomas ductal in situ e invasivo. A concordância do grau nuclear entre os carcinomas ductal in situ e invasivo foi muito boa.

CONCLUSÕES: A capacidade de invadir do carcinoma in situ parece independente dos genes HER-2/neu e TP53. A aparência geral do carcinoma de mama é formulada na iniciação da carcinogênese e os genes Her-2/neu e TP53 estão envolvidos.

PALAVRAS-CHAVE: Neoplasias mamárias. Carcinoma ductal in situ. Carcinoma de ductos infiltrante. Proteína c-erbB-2. Proteína p53. 